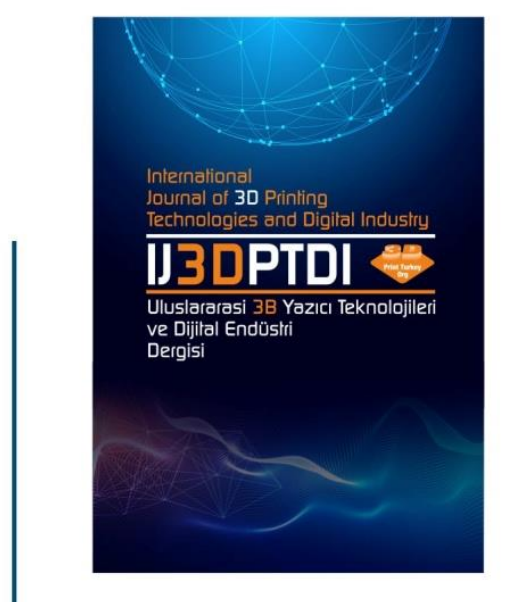

ULUSLARARASI 3B YAZICI TEKNOLOJILERI

VE DIJITAL ENDÜSTRI DERGISI

INTERNATIONAL JQURNAL OF 30 PRINTING TECHNQLOGIES AND DIGITAL INDUSTRY

IS5N:2602-3350 [Online]

URL: https://dergipark.org.tr/ij3dptdi

\title{
DIGITAL LEARNING WITH COVID-19 IN ALGERIA
}

Yazarlar (Authors): Hanane Zermane ${ }^{\circledR}$, Samia Aitouche

Bu makaleye şu şekilde atıfta bulunabilirsiniz (To cite to this article): Zermane H.,Aitouche S.." Digital Learning with Covid-19 in Algeria“, Int. J. of 3D Printing Tech. Dig. Ind., 4(2): 161-170, (2020). 


\title{
DIGITAL LEARNING WITH COVID-19 IN ALGERIA
}

\author{
Hanane Zermane ${ }^{\mathrm{a}}$ iD*, Samia Aitouche ${ }^{\mathrm{a}}$ iD \\ ${ }^{\text {a }}$ Batna 2 University, Laboratory of Automation and Computing, Faculty of Technology, Industrial Engineering \\ Department, ALGERIA \\ *Corresponding Author: h.zermane@univ-batna2.dz
}

(Received: 04.08.2020; Revised: 08.08.2020; Accepted: 12.08.2020)

\begin{abstract}
The coronavirus (COVID-19) pandemic poses an unprecedented global challenge, impacting profoundly on health and wellbeing, daily life, and the economy around the world. The COVID-19 pandemic has also changed education forever. The COVID-19 has resulted in schools shut all across the world. Globally, all children at schools or students at universities are out of the classroom. As a result, education has changed dramatically, with the notable rise of e-learning, whereby teaching is undertaken remotely and on digital platforms. Batna 2 University -situated in East of Algeria- is one of the universities suggested after the spread of COVID-19 in March, that online learning has been shown to increase retention of information, and take less time, meaning the changes coronavirus have caused might be here to stay. All institutes and departments, including the Industrial Engineering department, are started using the e-learning Moodle platform to publish courses for all degrees of study and establish online sessions, especially for Ph.D. students.
\end{abstract}

Keywords: Digital Learning. E-learning, COVID-19. Industrial Engineering. Media-based teaching.

\section{INTRODUCTION}

The distance education concept appeared years ago. However, its utility did not apply in all countries. Technology-based distance education is emerging as an increasingly visible feature of post-secondary education in the United States. Educators have the opportunity to define, design, and manage effective and robust teaching and learning systems, programs, and courses. As distance learning becomes a serious alternative to the standard classroom environment, enormous opportunities, and dilemmas present themselves for the players [1].

Distance education is the most convenient solution in critical situations, such as the COVID-19 pandemic. As a result of rapid virus proliferation, a revolutionary change is taking place in different sectors. Education is one of the many sectors in which the rapid virtualization process is taking place [2]. For reasons of health security, education, business, and even central and global administration and similar processes take place in the area of e-administration, where most activities are starting to be conducted online [3].

Most governments around the world have temporarily closed educational institutions in an attempt to contain the spread of the COVID-19 pandemic. These nationwide closures are impacting over $60 \%$ of the world's student population. Several other countries have implemented localized closures impacting millions of additional learners. UNESCO is supporting countries in their efforts to mitigate the immediate impact of school closures, particularly for more vulnerable and disadvantaged communities, and to facilitate the continuity of education for all through remote learning [4].

E-Learning is the key, popular, and supportive way to achieve this task. Schools and universities are radically transforming education by switching to online and e-learning forms. However, there is a large number of one-sided, fragmented, and disordered online education resources, which leads to low resource utilization and learning efficiency. Therefore, it becomes urgent to transfer the digital 
educational resources into a consistent knowledge system and services and launching Learning Management Systems solutions [5].

Several countries switched to e-learning, and students are responding to roll calls from their teachers online, such as in China [6], South Korea [7], USA, India [8], and Malaysia. In this late, and because learning from home cannot be a reality for some because they have no access to devices; in collaboration with YES and FrogAsia, YTL Foundation is providing free mobiles, which is Unavoidable Alternative during COVID-19 [9], with $120 \mathrm{~GB}$ worth of data (10 GB/month for 12 months) to students from B40 families so they can learn from home, and online learning materials to all students registered in Malaysian government schools to learn from home to keep children safe [10]. However, in many countries, even in the USA, according to The Guardian, US students are being asked to work remotely. But 22\% of homes don't have internet [11]. The Ministry of Education, Science, Culture, and Sport of Georgia has made the Microsoft teams platform available for all 2086 public schools in the country. The Education Management Information System has created the accounts for all teachers 55000 teachers and 530100 students) and have built-in the virtual classrooms for all classes and relevant subjects by default. Additional online instructions were published for teachers and students to use the system (MES 2020, Ministry of Education, Science, Culture, and Sport of Georgia to strengthen distance learning methods) [12]. Currently, in the spring semester of 2019-20, a total of 120 lecturers are assigned to courses, having different quantities of groups spread through the weekdays [13]. Corona transformed education from a stable sector to a less stable sector. It is a sector whose stability period has been relatively long, unlike other sectors such as tourism, transportation, economy, finance, meeting, and politics as well.

The surprise is that the home has become the school, university, institute, and college for all levels at a time when technological means are available for interactive communication events around the clock between two and more students and teachers. This sudden change was never expected to happen in this way, even though the world was sometimes experimenting with distance education to challenge some of the conditions that the learner or institution faces. The learner undoubtedly faces problems, the most important of which is cost, mobility and/or leaving work to enroll in university or institution.

Like every segment of society, engineering education has undergone profound change during the Covid19 pandemic. Shuttered campuses have turned to learn virtual, with engineering faculty forced to adopt new technology for teaching and to figure out how to turn what is often a hands-on education into a remote practice. The institution also suffers from challenges, the most important of which are financial problems and the inability of some people to join for several reasons. Here the cost has been reduced to half or below it sometimes, which encouraged many people wishing to study on its train, perhaps after a delay for one reason or another.

Over the past several decades, distance education has faced a fierce war from the official or monopolistic institution because it competes strongly with it, especially in terms of cost. In addition to this another war by institutions dealing with graduates, there was a clear distinction between graduates of distance education and face-to-face education, to the point that many institutions were even refusing to even deal or accept the request of a graduate of distance education. Distance learners may be a reason for this estrangement between them and the alumni market, as they often face unconventional or abnormal circumstances, delaying them from early enrollment in educational institutions, and at the time of improving conditions, they are forced to catch the ship.

The aim of this article is to throw a glance at the digital learning in Algerian universities with COVID19 and to try to find out the opportunities and margins of the movement that the digital delay has missed on Algeria in its response to the Corona crisis. If its content enumerates the gains, we have lost due to the current status of digitization in the country. However, at the same time, it defines the areas and workshops that must be opened soon, to try to take advantage of this crisis, and identify our digital weaknesses so that we can quickly strengthen them and advance this sector, in a way that positively affects the general situation in the country and preparing ourselves for the future. 


\section{ENGINEERING EDUCATION IN THE TIME OF COVID-19}

\subsection{Online Courses}

There are nearly $9.3 \mathrm{~m}$ students enrolled across more than 27,000 educational establishments monitored by 749,232 officials ( $89.9 \%$ of whom are educational supervisors). Enrolment figures have increased by $6.8 \%$ since 2000; as of 2018, there were over $1 \mathrm{~m}$ students enrolled at the lower education level. Education is compulsory until the age of 16 , at the end of lower secondary school when students take the Middle School Certificate (Brevet d'Enseignement Moyen, BEM) exam to determine whether or not they can continue on to upper secondary education. The pass rate for both the BEM and the baccalaureate, which is taken at the end of upper secondary school, hovers close to $60 \%$ [14].

One of the most significant casualties of the COVID-19 pandemic and the resultant lockdown has been institutionalized education. Schools have been shut to prevent the spread of the virus, and this has given way to online classrooms, a very new concept in Algeria for schools and universities. Figure 1 corresponds to the number of learners enrolled at pre-primary, primary, lower-secondary, and uppersecondary levels of education [ISCED levels 0 to 3], as well as at tertiary education levels [ISCED levels 5 to 8 ] in Algeria until 13 July 2020. Enrolment figures based on the latest UNESCO Institute for Statistics data [4].

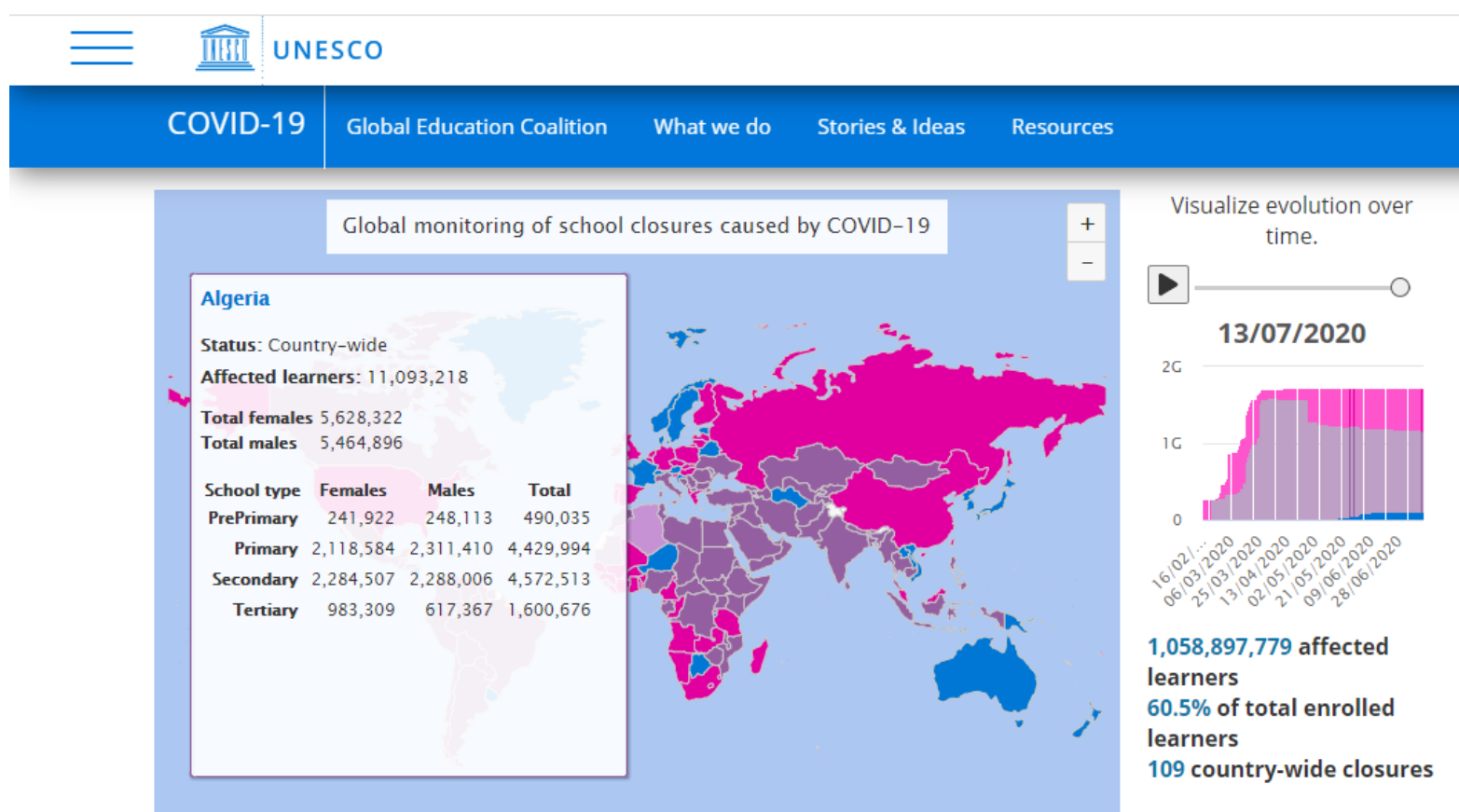

Figure 1. E-learning system of Batna 2 University.

In the field of education and distance work, the Corona crisis showed with the suspension of studies and the presence of students in the house, limited solutions in the hands of the ministry, in the absence of floors and platforms at the level for distance education, what was put on YouTube and some sites is just an attempt to mitigate the damage, in the absence of designed lessons Especially for distance learning floors and with the ability to communicate, interact and evaluate, it is difficult to ask students and students to follow lessons and dry content that compensate for education in schools.

According to Djamila Khiar who is president of the Fédération nationale des associations de parents d'élèves, for nearly five years: "Distance learning didn't exist, other than correspondence courses. There had been a few initiatives previously, and there was a television station that had classes to help study for the baccalaureate. With the coronavirus, we had to move quickly and implement distance learning. 
There are some courses online, but not everyone is lucky enough to have a computer or an internet connection. We have a lot of large families, and it is difficult for the children to find a quiet spot in the house. So, in our situation, distance learning with television is more democratic. It used to be that we always focused on the baccalaureate, but this time we saw that all classes were affected. It is a good thing that we realized this, the coronavirus educated us and made us realize that we need to train teachers in distance learning, and how to be able to engage with children. There was great solidarity, and our teachers tried their best, but they do not have the methodology required for distance learning. However, the classes that were organized ran on the six national television stations, and we have asked for a special station that will run classes as long as the school is closed" [15].

Djamila Khiar met with the Ministry on March 27 and suggested that the teachers get training as quickly as possible and reorganizing the school year; this year, we were lucky that the first two trimesters were stable compared to other years when there were strikes. The children completed $80 \%$ of the program. The lockdown began one week before the school holidays following the second trimester, which is the longest. The Ministry was asked to end the school year now. He consulted with 16 unions and the three parents' associations, and we all agreed that schools should not reopen. The third trimester is only three to four weeks long; sometimes, there are more than 40 children per class, so it's impossible to put in place the necessary sanitary measures. The baccalaureate exam that usually takes place in June be postponed until September. A roadmap is suggested so that teachers can prepare, and students can get back to learning without endangering their health and that of their families [15].

E-learning initiatives have advanced significantly as institutions and companies seek to overcome budgetary constraints while providing quality education and training services for students and employees. On the public side, the National Centre for Professional Distance Education (Centre National de la Formation et de l'Enseignement Professionnels à Distance, CNEPD) became one of the first public institutions in the country to set up an e-learning platform in January 2018. Aimed at individuals seeking to expand their professional and technical competences, the CNEPD e-learning platform expands educational opportunities to individuals with physical or geographical constraints. The Algerian e-learning platform BeeForm launched in November 2017 with the aim of providing companies and public institutions with digital tools for training on a mass level. Among the first signatories of agreements with BeeForm were institutions from both the public and private sectors, including the public universities School of Commercial High Studies and Research Centre for Scientific and Technical Information, as well as local IT consultancy COSOFT Group and Algerian cloud services provider ISSAL, among other private firms. The Tipaza Smart City project has also signed an agreement with BeeForm [14].

The Higher Education sector in Algeria, in a responsible approach, based on the commitment of the entire community of the university teachers, aims to maintain the academic relationship, between the teachers and their students, and put online teaching content in their different forms of courses, tutorials and practical works (when practical works are available online). Universities across Algeria in their turn, including the University of BATNA 2 have created an E-learning System [16]. The National Bureau for Distance Education and Training (Office national d'éducation et de formation à distance) of the Ministry of Higher Education provides online learning platforms in different subjects for all academic levels. This space will not be used just to host documents for download. It is an area to simulate a real classroom and meet students, using the interactives and collaboratives resources offered by the system. Students can download documents directly from the website of the lecturer or through the online courses available in the Department Website.

Lecturers have moved to virtual classrooms, all thanks to tools such as Zoom, Google Hangouts, and Microsoft Teams. Nevertheless, there are some still struggling to get online. The quick turn to platforms like Zoom is disrupting curricula, particularly for professors less equipped to navigate the internet and the particularities of managing a classroom mediated by a screen and microphone. Several professors cancel a class because they had technical difficulties, trouble with WiFi, or were simply panicked over the prospect of teaching the full class over the new platform [17]. Lecturers having managed scientific and administrative academic structures for a long time, they put all their experiences and skills to the 
benefit of presenting their courses online in the same way as offline, and students can give their feedback through lecturers' emails.

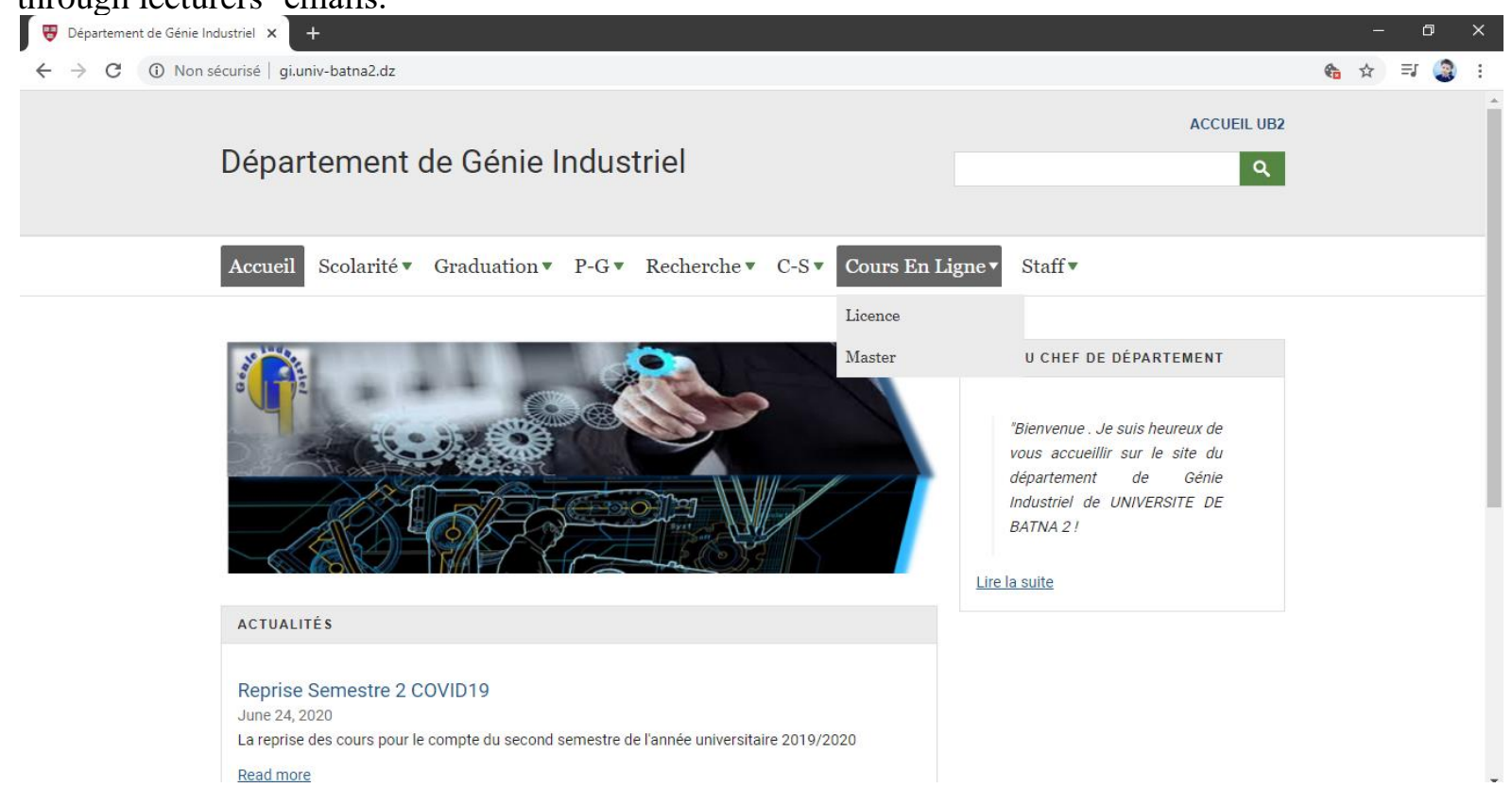

Figure 2. E-learning system of Batna 2 University.

Like other institutions of industrial engineering around the world such as NSPE (National Society of Professional Engineers) [18], during this pandemic, the Industrial Engineering Department students of Batna 2 university faced a major challenge to complete their educational process in time. It was to conduct semester that were due to be held in the end of March 2020 and year-end examinations that were due to be held at the end of June but had to be postponed as all students were required to vacate universities' residences and return home.

The final-year students have not completed all academic requirements especially their training in industrial companies in domains such as automation, supply chain management, the completion of examinations is also a critical step to complete their academic journey. The need to complete their courses make e-learning a permanent solution. Before the COVID-19 crisis, the state has also sought to collaborate with private industrial players in order to reinforce and complement public programs in vocational training.

In the last decade, over 13,000 agreements between industry and academic institutions have been signed, resulting in the training of 650,000 new workers. In October 2018, Huawei Algeria signed cooperation agreements with the MESRS and two public universities to establish an academy of excellence, which is scheduled to commence operations in November 2019. Huawei Algeria seeks to foster the development of the country's ICT ecosystem and intends to build 30 further academies of excellence in the next three years in collaboration with the MESRS to train university students in the latest technological innovations. In the future, this collaboration between university and industry must use Industry 4.0 technologies and their applications to fight COVID-19 pandemic [19]. Figure 3 presents a web page of lecturer at the Industrial Engineering Department with online courses [14]. 

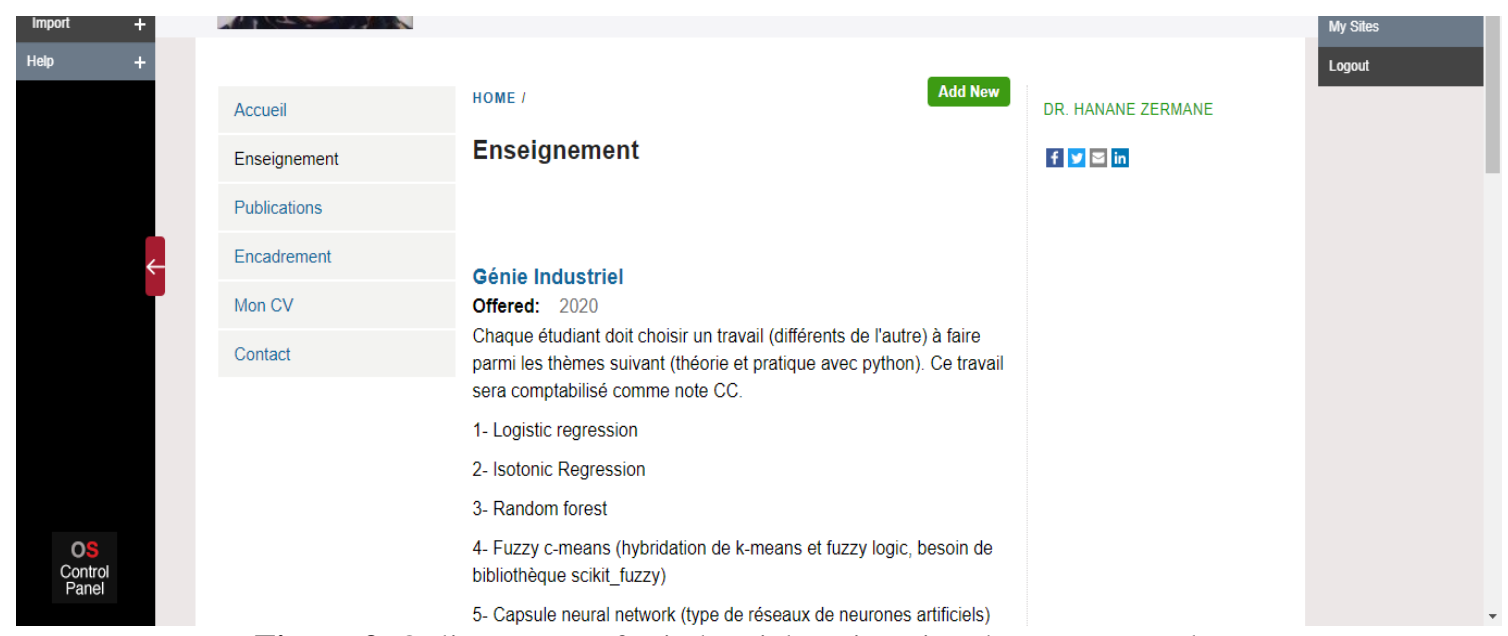

Figure 3. Online courses for industrial engineering department students.

Even if the online classes are essential actually with the COVID-19, there are advantages and disadvantages. Whatever the enabling technology is only as good as the teachers and the ability of the students to grasp the new teaching technique. One of the teachers felt students are more responsive and active in online classrooms, compared to when they are in physical ones. This could be because this is a new concept, and they are excited to explore it with the teachers. They also do not get distracted by their classmates, which frequently happens in a regular class [20].

\subsection{Webinars}

Several webinars are offered to students of the Industrial Engineering Department. For the first webinar, we will be honored to receive a special guest Mr. Mohamed Ibrahim Ali Hassan, Senior Drilling Consultant \& Instructor here in Algeria. During his presentation, Mr. Mohamed Ali Hassan shared his experience with students about Petroleum Cybernetics \& Industry 4.0 Transformation.

The second webinar presented as part of the Online Learning Program by Mr. Sofiane Galou, Manager of the training center of Siemens Algeria. He provided an online plenary based on the TIA Portal and programming. This online training allowed participants to learn about automation and know the operating principle of PLCs and get to know the TIA Portal and the various Siemens PLCs. The online course contained an introduction to the TIA Portal, programming concept, loading, and visualization of the integration of a hardware configuration via the TIA Selection Tool. Mr. Galou presented another plenary on the concept of digitalization, The areas of application of digitalization, Advantages, and Perspectives.

One of the online learning programs is presented by Mr. Abdelhafid Hachemaoui Head of Prevention Service at the Operations Department of El Gassi, Sonatrach-DP, about the Leadership and HSE culture in a company. Mr. Abdelhak Ladmia, the expert on Petroleum Engineering, introduced the role of the engineer to manage time and cost as a second live podcast. During his presentation, students learned how an engineer manages large-scale projects and what time management tips can offer. In the third live podcast, Mrs. Chada talked about digital technology in the oil and gas industry; she is well versed and experienced in this field.

\subsection{Students' Engineering Solutions}

Around the country, engineering schools and departments are stepping up to help with the global pandemic. From donating their protective equipment to 3D printing masks and face shields to modeling the pandemic and more, engineers are doing what they're best at solving problems and protecting the public.

As the coronavirus continues to sicken millions of people across the United States and the world, Berkeley researchers and students are contributing their time and expertise to combat the outbreak. From providing real-time localized information on infections to more efficiently resterilizing N95 masks, the 
engineering community is focusing on ways to inform the public and aid beleaguered healthcare workers are facing critical shortages of medical supplies [21].

In Algeria, students and scientific laboratories of the University of Batna 2 play an essential role in the innovation and also have a prospect that may change the reality of the national economy through innovations and ideas among students that it may materialize in reality, with lower costs and better benefits. One of these scientific clubs is YALA in Batna 2 university. Students of this club are realized a remote thermometer to measure human temperature remotely. The young researchers and the device are presented in parts (a), (b), (c) shown in Figure 4.

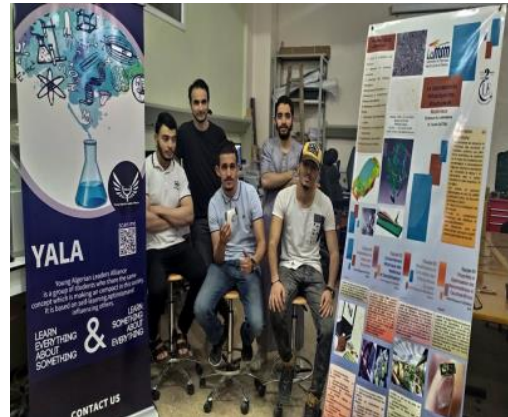

(a)

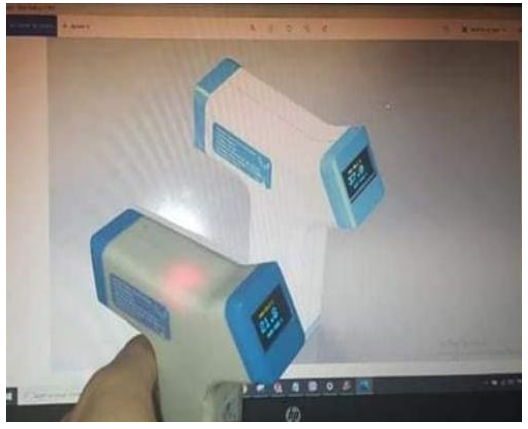

(b)

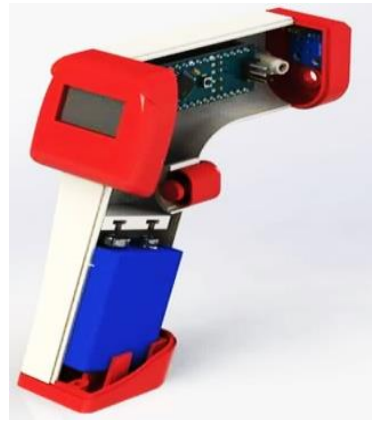

(c)

Figure 4. Remote thermometer students' engineering solutions with COVID-19.

One of the benefits of the strategy of the collaboration between the research sector and the industrial sector is the cooperation to confront the Covid-19 pandemic by realizing the prototypes of students. After almost completing the laboratory model, it was manufactured by researchers of the University of Batna 2. Manufacturing the industrial model of the remote thermometer is established in collaboration with the National Institution for Electronic Industries ENIE engineers and the young researchers from the scientific club and The Laboratory of Structural Mechanics and Materials Laboratory (LAMSM) of Batna 2 University. After the manufacture of the final model, it will be distributed to the health sector throughout the country to help in the contribution of preventing COVID-19.

The second project consists of the development of a particular medical robot. This project is being launched with various technologies under the slogan "we are with you". The robot will perform several tasks, including:

- Get to know patients remotely with a camera.

- Speak via an automatic microphone.

- Calculating the human temperature with thermal sensors.

- Calculating the heartbeat.

- Delivery of medicine and food to patients.

- Hand sanitizing.

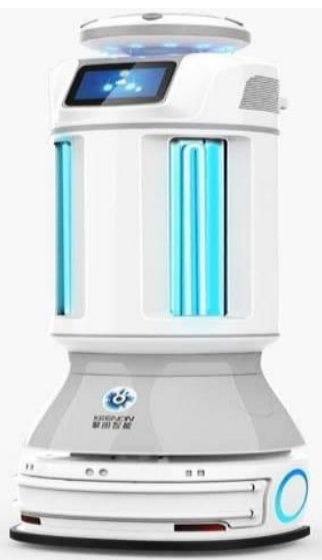

Figure 5. prototype of the medical robot. 


\section{CONCLUSION}

The current COVID 19 crisis and its massive demand to urgently adapt face-to-face training to distant training methods is an opportunity to address of redefining educational engineering. This social demand, at first glance, may seem explicit, develop appropriate and free tools for learning, especially for poor students. Algeria is one of the emerging countries that need to develop digital learning and education, at the same time, profit from universal resources offered by several organizations.

The need to plan to continue distance learning and implement a system for the future is indispensable. In the years to come, we should be better equipped; everyone agrees that there are many possibilities if we can have a special television station and train our teachers. We can get organized, but nothing replaces the classroom, even for a child psychologically, they have their friends, a place to be silly, an environment that is their own. At home, things are not always easy. We know better what to expect now, and we have learned that families have an essential role to play. Before, we relied entirely on the national education system and did not fully play our role. However, the coronavirus showed us the importance of being present and following up on what the children are doing with distance learning. Children are not used to distancing learning; on television, they can not react or ask questions.

As an example of distance learning solutions, UNESCO offers a comprehensive list of educational applications, platforms, and resources that aim to help parents, teachers, schools, and school administrators facilitate student learning and provide social care and interaction during periods of school closure. Most of the solutions curated are free, and many cater to multiple languages. While these solutions do not carry UNESCO's explicit endorsement, they tend to have a broad reach, a strong userbase, and evidence of impact. They are categorized based on distance learning needs, but most of them offer functionalities across multiple categories [22]. The learning response to COVID-19 was triggered by the WHO Emergency Committee too. An introductory COVID-19 course was launched on OpenWHO.org. First published in English, the course has since been translated into 15 languages [23].

The outbreak of COVID-19 in Europe and the necessary national measures taken to tackle the spread of the virus may cause significant disruption to the provision of education, training, and mobility opportunities for learners, teachers, and educators across the European Union (EU). EU leads to help ensure continuity in education and training activities; he proposed a wide range of online learning materials made available online. An upcoming review of the Digital Education Action Plan in mid-2020 will further support the development of online learning at different levels of education across Europe. The Digital Education Action Plan presents measures to help the Member States and education and training institutions to reap the opportunities and meet the challenges presented by the digital age. It will be implemented by the end of 2020. The Commission is expected to adopt an updated Action Plan in September 2020. The consultation seeks to gather the views of citizens, institutions, and organizations on their experiences and expectations during the COVID-19 crisis (both to-date and in the recovery period), as well as their visions for the future of digital education [24].

Though COVID-19 has had a severe impact on standard educational progress, universities may take this unforeseen opportunity to detect deficiencies and speed up reform of online education through innovative course content, state-of-the-art technology, and efficient management. We have to turn this emergency into an occasion to promote international collaboration further and share experiences, knowledge, and resources to build a global online education network [25].

\section{ACKNOWLEDGE}

This paper and the research behind it would not have been possible without the exceptional support of students of the scientific club YALA at Batna 2 University, SPE Batna Chapter, and colleagues who provided insight and expertise that greatly assisted the research. I wish to extend my special thanks and greet everyone who has supported the creation of this work. 


\section{REFERENCES}

[1] D. A. Matthews, Distance Education: What Is It? Utilization of Distance Education in Higher Education in the United States, IGI Global. Carlow College, USA, 2002.

[2] P. Leonardi, "You're going digital - Now what?," MIT Sloan Management Review, 2020.

[3] Ł. Sułkowski, "Covid-19 Pandemic; Recession, Virtual Revolution Leading to De-globalization?," J. Intercult. Manag., vol. 12, no. 1, Pages. 1-11, 2020.

[4] UNESCO, "School closures caused by Coronavirus (Covid-19)," UNESCO, 2020. https://en.unesco.org/themes/education-emergencies/coronavirus-school-closures, July 14, 2020.

[5] F. Tian, Q. Zheng, and K. M. Chao, "Current and future of technologies and services in smart e-learning," Serv. Oriented Comput. Appl., vol. 14, no. 1, Pages. 1-3, 2020.

[6] M. A. Peters et al., "China's Internationalized Higher Education During Covid-19: Collective Student Autoethnography," Postdigital Sci. Educ., 2020.

[7] Bicker Laura, "Coronavirus: How South Korea is teaching empty classrooms," BBC News, 2020. https://www.bbc.com/news/world-asia-52230371 July 14, 2020.

[8] NITIE, "Industrial Engineering Pioneer, NITIE Mumbai conducts final exams online during Covid19 - Times of India,” 2020. [Online]. Available: https://www.nitie.edu/ July 14, 2020.

[9] A. Naciri, M. A. Baba, A. Achbani, and A. Kharbach, "Mobile Learning in Higher Education: Unavoidable Alternative during COVID-19," Aquademia, vol. 4, no. 1, ep20016, 2020.

[10] YTL Foundation, “Learn From Home,” 2020. https://ytlfoundation.org/learnfromhome/ July 14, 2020.

[11] The Guardian, "Students across the US are being asked to work remotely," 2020. https://www.theguardian.com/commentisfree/2020/mar/23/us-students-are-being-asked-to-work-remotelybut-22-of-homes-dont-have-internet. July 14, 2020.

[12] G. Basilaia and D. Kvavadze, "Transition to Online Education in Schools during a SARS-CoV-2 Coronavirus (COVID-19) Pandemic in Georgia," Pedagog. Res., vol. 5, no. 4, Pages. 1-9, 2020.

[13] G. Basilaia, "Replacing the Classic Learning Form at Universities as an Immediate Response to the COVID19 Virus Infection in Georgia,” Int. J. Res. Appl. Sci. Eng. Technol., vol. 8, no. 3, Pages. 101-108, 2020.

[14] Oxford Business Group, "Reforms to Algeria's education system to expand capacity and modernise curricula | Algeria 2018 | Oxford Business Group," 2018. https://oxfordbusinessgroup.com/overview/contemporarytutelage-transforming-education-system-expand-capacity-and-prepare-students-modern-age.html July 14, 2020 .

[15] ETF (European Training Foundation), "Algeria_ distance learning for students _ ETF," 2020. https://www.etf.europa.eu/en/news-and-events/news/algeria-distance-learning-students. July 14, 2020.

[16] “UB2-Elearning,” 2020. www.univ-batna2.dz. July 14, 2020.

[17] Y. Iwai, "Online Learning during the COVID-19 Pandemic - Scientific American Blog Network," Springer Nature, Scientific American Blog Network, 2020. https://blogs.scientificamerican.com/observations/onlinelearning-during-the-covid-19-pandemic/ July 14, 2020.

[18] NSPE, "Engineering Education in the Time of Covid _ National Society of Professional Engineers," 2020. [Online]. https://www.nspe.org/resources/pe-magazine/may-2020/engineering-education-the-timecovid.html July 14, 2020.

[19] M. Javaid, A. Haleem, R. Vaishya, S. Bahl, and R. Suman, "Since January 2020 Elsevier has created a COVID-19 resource centre with free information in English and Mandarin on the novel coronavirus COVID- 
19. The COVID-19 resource centre is hosted on Elsevier Connect, the company's public news and information," January, 2020.

[20] S. Saha, "Coronavirus (COVID-19), Why is online classes important, how to make them engaging," 2020. https://indianexpress.com/article/technology/tech-news-technology/online-classes-why-teaching-learningremotely-learning-experience-6367765/. July 14, 2020.

[21] Berkeley Engineering, "Engineering faculty, students mobilize to help COVID-19 efforts _ Berkeley Engineering," 2020. https://engineering.berkeley.edu/engineering-faculty-students-mobilize-to-help-covid19-efforts/ July 14, 2020.

[22] UNESCO, “Distance learning solutions," Journal of European Industrial Training, 1999. https://en.unesco.org/covid19/educationresponse/solutions July 14, 2020.

[23] R. George et al., “An Analysis of the Growth in Uptake of OpenWHO's Online Learning Resources for COVID-19.," Stud. Health Technol. Inform., vol. 272, no. January, Pages. 284-287, 2020.

[24] European Union, "Digital Education Action Plan," 2020. https://ec.europa.eu/education/education-in-theeu/digital-education-action-plan_es. July 14, 2020.

[25] L. Sun, Y. Tang, and W. Zuo, “Coronavirus pushes education online,” Nat. Mater., vol. 19, no. 6, Page. 687, 2020 . 